Arkivoc

Free to Authors and Readers
A Platinum Open Access Journal for Organic Chemistry
Paper

Arkivoc 2021, part vi, 131-147

\title{
Preparation and thermally-induced self-assembly behaviour of elastin-like peptide side-chain polymer-gold nanoparticle (ESP-GNP) hybrids
}

\author{
Jingyi Zong, ${ }^{a}$ Steven L. Cobb, ${ }^{a}$ and Neil R. Cameron $*^{b, c}$ \\ a Department of Chemistry, Durham University, South Rd., Durham, DH1 3LE, U.K. \\ ${ }^{b}$ Department of Materials Science and Engineering, Monash University, 22 Alliance Lane, Clayton, Victoria \\ 3800, Australia \\ ' School of Engineering, University of Warwick, Coventry, CV4 7AL, U.K \\ Email: neil.cameron@monash.edu
}

Dedicated to Professor Philip Hodge, recognising his contributions to polymers in synthesis over 45 years

Received 07-02-2021

Accepted 08-07-2021

Published on line 08-16-2021

\begin{abstract}
Thermoresponsive gold nanoparticles were prepared by conjugation of short pentapeptide sequences, containing the elastin-like peptide (ELP) repeat unit Val-Pro-Gly-Val-Gly (VPGVG), to a well-defined active ester prepolymer, poly(pentafluorophenyl acrylate) (pPFPA), itself prepared by RAFT polymerisation. Polymers with number-average chain lengths of 25,50, 75 and 100 were prepared. The cloud points of their aqueous solutions was found to decrease with chain length and peptide sequence, and varied from 76 to $42{ }^{\circ} \mathrm{C}$. Circular dichroism indicated that the cloud point behaviour was accompanied by a reversible change in peptide conformation from a random coil to a $\beta$-turn. The resulting thermoresponsive elastin peptide side-chain polymers (ESPs) were then conjugated to gold nanoparticles (GNPs) by ligand exchange. The resulting ESPGNPs similarly displayed thermo-reversible aggregation with transition temperature $\left(T_{t}\right)$ values of 65 and $35{ }^{\circ} \mathrm{C}$ for ESPs of chain length 75 and 100, respectively.
\end{abstract}
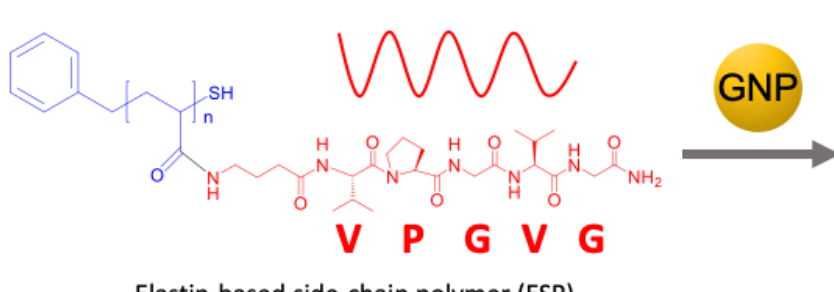

Elastin-based side-chain polymer (ESP)

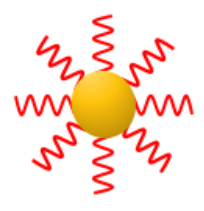

ESP-GNPS

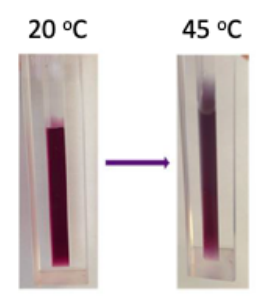$$
\text { . }
$$

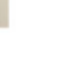

Keywords: Gold nanoparticles, pentapeptide, cloud points, thermoresponsive, circular dichroism 


\section{Introduction}

Metallic nanomaterials continue to serve as a crucial platform for many advanced technologies in therapy, diagnostics, sensing and catalysis. In particular, gold nanoparticles play a key role because of their easily controlled size, shape and corona composition; together, these parameters produce a suite of nanomaterials with properties that are well-suited to a myriad of applications. The generation of gold nanoparticulate systems that are robust and reliable requires a stable surface coating that serves not only to stabilise the nanoparticles when dispersed in solution, but also provides a means by which they can sense, detect and otherwise interact with their external environment. An enormous variety of molecules and materials have been employed as coatings on gold nanoparticles, including, amongst others, small molecules, synthetic polymers, natural polymers, peptides, proteins and nucleotides. Of these, peptides have received considerable attention because of their rich chemical diversity and innate biological function. In recent years, many examples of peptide-functionalised gold nanoparticles have been described in the literature, for applications mainly in targeted drug delivery, oligonucleotide delivery, cancer therapy and detection ${ }^{1}$.

One interesting phenomenon that can be engineered with peptide-functionalised gold nanoparticles is reversible self-assembly. The aggregation state can be altered from assembled to disassembled by various triggers, including enzyme activity ${ }^{2,}{ }^{3}$, metal-ligand coordination ${ }^{4}, \mathrm{pH}^{5-7}$ and temperature ${ }^{8,}{ }^{9}$. The surface plasmon resonance band of GNPs undergoes a red-shift upon nanoparticle aggregation, causing a colour change of the peptide-GNP solution from red to violet. This has been used extensively as the basis of colourimetric sensors for a wide variety of species. Elastin-like peptides (ELPS), which are composed of repeating pentapeptide sequences of the form VPGXG where $X$ represents any naturally occurring amino acid other than proline, undergo a reversible conformational transition from random coil (hydrophilic) to $\beta$-spiral (hydrophobic) upon increasing solution temperature beyond a transition temperature (the value of which depends on a number of factors) ${ }^{10}$. This causes, reversibly, precipitation of the peptide from solution. Accordingly, ELPs anchored onto GNP surfaces impart to the nanoparticles the same reversible assembly behaviour. In previous work, we demonstrated that a single pentapeptide repeat unit (i.e. VPGVG) could cause the same thermoresponsive behaviour in GNPs, so long as the C-terminus of the peptide was not in its free carboxylic acid form ${ }^{9}$. VPGVG-GNPs were therefore shown to be thermoresponsive under near-physiological conditions (a transition temperature of $40{ }^{\circ} \mathrm{C}$ was recorded at $\mathrm{pH}=7.4$ ).

Whilst this represents a significant advance, and opens the possibility of the use of simple, short peptide-functionalised GNPs for biomaterials applications, it is difficult to control the transition temperature without tuning the peptide sequence. It has been shown that VPGVG units conjugated to synthetic polymer backbones produce thermoresponsive polymers, the transition temperature of which is dependent on chain length in a linear manner ${ }^{11,12}$. In this work, we show that the transition temperature of peptide-modified GNPs can similarly be modulated by preparing ELP peptide side-chain polymers (ESPs) of different length, and subsequently conjugating these polymers to GNP surfaces. This results in ESP-GNPs with transition temperatures in the range of 45 to greater than $100{ }^{\circ} \mathrm{C}$, at neutral $\mathrm{pH}$. The polymers were prepared by RAFT polymerisation, which not only allows control over polymer chain length but also installs a thiol moiety at one chain end, with which to conjugate the polymers onto GNPs by simple ligand substitution. 


\section{Results and Discussion}

Reversible addition fragmentation chain transfer (RAFT) polymerization was used to polymerize the monomer pentafluorophenyl acrylate (PFPA) in the presence of benzyl 2-hydroxyethyl carbonotrithioate as a chain transfer agent in benzene at $70{ }^{\circ} \mathrm{C}$. PFPA is an activated ester which has been widely applied in the synthesis of biologically active polymers ${ }^{13}, 14$ and which has also been shown to be a good candidate for RAFT polymerization. ${ }^{15}$ It was synthesised by reaction between pentafluorophenol and acryloyl chloride (see Supporting Material). Poly(pentafluorophenyl acrylate) (pPFPA) has excellent solubility in common organic solvents and high reactivity compared to conventional activated esters. Furthermore, it is easy to monitor the reaction of the PFP ester groups using ${ }^{19} \mathrm{~F}$ NMR spectroscopy. The trithiocarbonate polymer end group can readily be converted to a thiol through aminolysis, which has advantageous properties for attachment to gold nanoparticle surfaces. The reaction scheme for the preparation of pPFPA by RAFT polymerisation is shown in Scheme S1.

Different degrees of polymerisation (DP) of pPFPA, from 25 to 100, were prepared (Table 1). The purified polymers were analyzed by GPC, ${ }^{1} \mathrm{H}$ NMR and ${ }^{19} \mathrm{~F}$ NMR spectroscopies (see Supporting Material). The molecular weights obtained by GPC are generally in very good accord with the theoretical molecular weights, as shown in Table 1. The GPC also indicated monomodal distributions with low dispersities $\left(\Theta_{M}\right)$. The ${ }^{1} H$ NMR spectrum of the purified pPFPA polymers showed characteristic signals from backbone protons around 2.0 and $3.0 \mathrm{ppm}$ (Figure S4). The aromatic signal at $7.2 \mathrm{ppm}$ verified the presence of the RAFT agent. By comparing the phenyl protons and backbone proton integrals, the degree of polymerization (DP) could be determined and thus the molecular weight calculated. The ${ }^{19} \mathrm{~F} N M R$ analysis confirmed the expected structure with three signals at $-153,-158$ and $-162 \mathrm{ppm}$ attributed to the pentafluorophenyl group. Complementary FTIR spectroscopy showed a carbonyl absorption peak of pentafluorophenyl ester at $1782 \mathrm{~cm}^{-1}$ and an aromatic absorption peak at $1516 \mathrm{~cm}^{-1}$ as shown in Figure S5.

Table 1. Polymerization Reaction Conditions and Characterisation Data for the Preparation of pPFPA

\begin{tabular}{lllllll}
\hline Polymer & {$[\mathrm{M}] /[\mathrm{RAFT}] /[\mathrm{l}]$} & $\mathrm{M}_{\mathrm{n}, \text { theor }}\left(\mathrm{g} \cdot \mathrm{mol}^{-1}\right)$ & $\mathrm{M}_{\mathrm{n}, \mathrm{GPC}}\left(\mathrm{g} \cdot \mathrm{mol}^{-1}\right)$ & $\bigoplus_{\mathrm{M}}$ & $\begin{array}{l}\mathrm{M}_{\mathrm{n}, \mathrm{NMR}} \\
\left(\mathrm{g} \cdot \mathrm{mol}^{-1}\right)\end{array}$ & $\begin{array}{l}\text { Yield } \\
(\%)\end{array}$ \\
\hline pPFPA-25 & $25 / 1 / 0.2$ & 6,194 & 8,200 & 1.26 & 6,200 & 65 \\
pPFPA-50 & $50 / 1 / 0.2$ & 12,144 & 15,700 & 1.27 & 10,700 & 60 \\
pPFPA-75 & $75 / 1 / 0.2$ & 18,094 & 16,300 & 1.26 & 14,500 & 70 \\
pPFPA-100 & $100 / 1 / 0.5$ & 24,044 & 23,500 & 1.19 & 19,500 & 69 \\
\hline
\end{tabular}

Solid-phase peptide synthesis with an Fmoc-protecting group strategy and a Rink Amide resin was employed for the preparation of the peptides used to prepare elastin-like peptide side-chain polymers (ESPs). The sequences of the peptides prepared are shown in Table 2. 
Table 2. Sequences and Structures of Synthesised Peptides

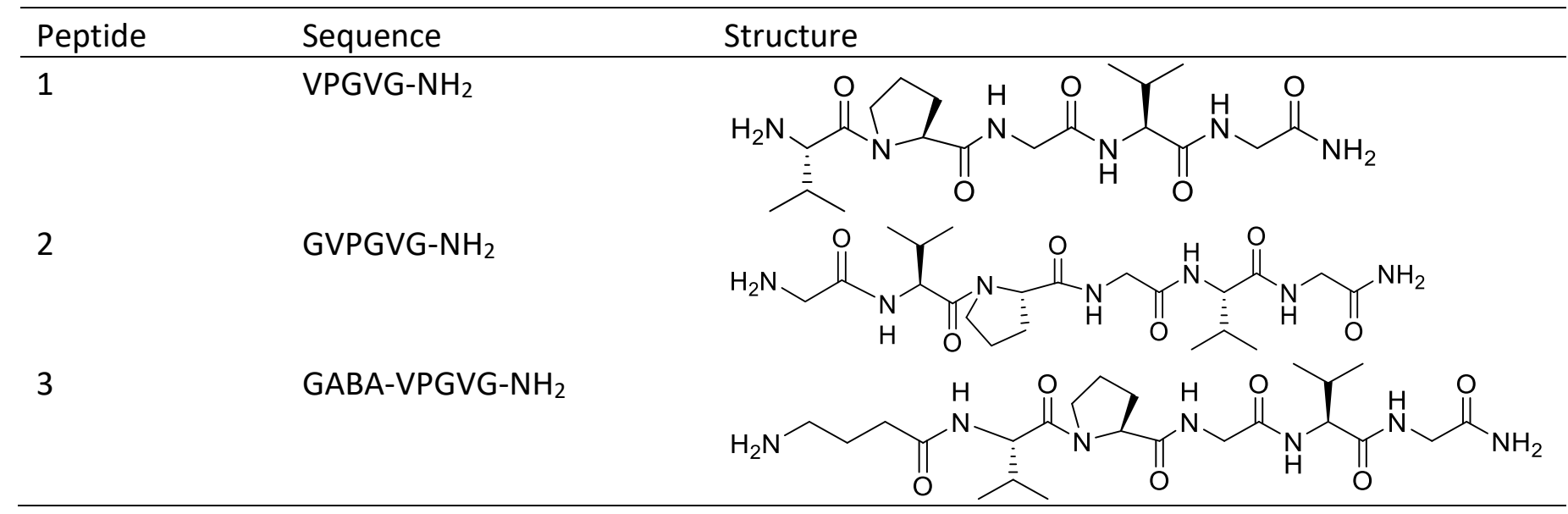

The preparation method was the same as that used previously, details can be found in our previous publication ${ }^{9}$. Crude products were purified by semi-preparative HPLC and obtained in $50-56 \%$ yield. The identity of each peptide was confirmed by LC-MS and purity was demonstrated by analytical HPLC (see Supplementary Material).

Short elastin-like peptides (ELPS) were coupled to PPFPA by reaction between the peptide $\mathrm{N}$-terminal amino group and the side-chain pentafluorophenyl esters of pPFPA in the presence of 1.5 equivalents of triethylamine. A ratio of 1.4:1 [peptide]/[pPFPA] was chosen to ensure full conversion of the activated ester. A ratio higher than stoichiometric is not expected to have a significant impact on the yield. ${ }^{14}$ When the reaction was finished, the solution was dialyzed against water for 3 days to remove any unreacted peptides. As proof of a successful reaction, the solubility of the polymer was transformed from hydrophobic pPFPA to hydrophilic elastin-like peptide side-chain polymer (ESP). A reaction scheme for the preparation of all 3 ESP variants is shown in Scheme 1. Table 3 shows the characterisation data for all the ESPs.

The elastin-based side chain polymers were analysed by ${ }^{1} \mathrm{H} N M R,{ }^{19} \mathrm{~F} N M R$ and FT-IR spectroscopies. The ${ }^{19} \mathrm{~F}$ NMR spectrum is especially useful in determining the extent of reaction of the pentafluorophenyl esters. For low DP polymers PF25-VPGVG and PF50-VPGVG, the ${ }^{19} \mathrm{~F}$ NMR spectra showed no signals at -153, 158 and -162 ppm from the pentafluorophenyl group. However, for the higher DP polymers PF75-VPGVG and PF100-VPGVG, the reactions were found to be incomplete as the ${ }^{19} \mathrm{~F} N M R$ spectra showed very small peaks in this area. In support, ATR-FTIR spectra of both polymers showed a small carbonyl absorption peak at $1782 \mathrm{~cm}^{-}$ ${ }^{1}$ while no such peaks were seen in ATR-FTIR spectra of the lower DP polymers. These results indicate that the longer the polymer chain, the more difficult the reaction. Also, because of the structure of peptide VPGVG, the amine of amino acid valine is quite hindered and slow to react with the pentafluorophenyl ester. Therefore, we synthesised peptides with an extra glycine (GVPGVG- $\mathrm{NH}_{2}$ ) or a 4-aminobutanoic acid linker (HGABA(VPGVG)-NH 2 ) to facilitate reaction with pPFPA-75 and pPFPA-100. 


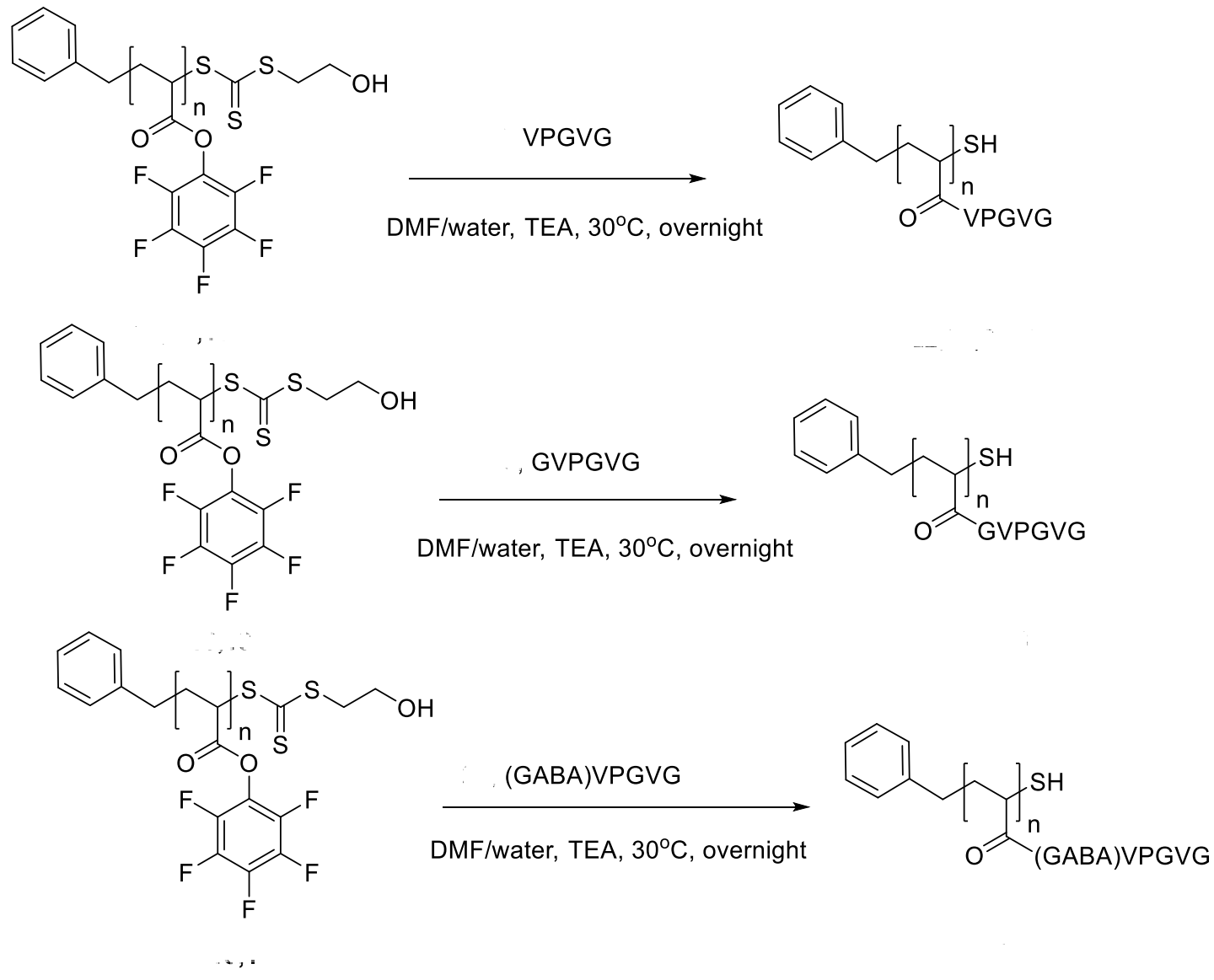

Scheme 1. Preparation of ESPs by coupling peptides to pPFPA polymers.

Table 3. Characterisation date for peptide-polymer hybrids

\begin{tabular}{lllll}
\hline ESPa $^{\mathbf{a}}$ & $\mathbf{M}_{\mathbf{n}, \text { theor }}\left(\mathbf{g} \cdot \mathbf{m o l}^{-\mathbf{1}}\right)$ & $\mathbf{M}_{\mathbf{n}, \mathbf{G P C}}\left(\mathbf{g} \cdot \mathbf{m o l}^{-\mathbf{1}}\right)$ & $\boldsymbol{D}_{\mathbf{M}}$ & Yield (\%) \\
\hline PF25-VPGVG & 12,125 & 5,600 & 1.31 & 71 \\
PF50-VPGVG & 21,245 & 6,400 & 1.46 & 87 \\
PF75-VPGVG & 28,925 & 10,100 & 1.30 & 83 \\
PF75-GVPGVG & 32,345 & 10,600 & 1.22 & 81 \\
PF75-GABA(VPGVG) & 34,025 & 11,300 & 1.23 & 79 \\
PF100-VPGVG & 39,005 & 11,500 & 1.26 & 80 \\
PF100-GVPGVG & 43,622 & 13,000 & 1.25 & 80 \\
PF100-GABA(VPGVG) & 45,890 & 13,400 & 1.27 & 76 \\
\hline
\end{tabular}

a $[$ Polymer $] /[$ Peptide]/[TEA $]=1 / 1.4 / 1.4$

The ${ }^{1} \mathrm{H}$ NMR and ${ }^{19} \mathrm{~F}$ NMR spectra of PF75-GVPGVG-NH 2 are shown in Figure 1 . The absence of the backbone proton signal at $3.0 \mathrm{ppm}$ indicates an efficient modification of the pentafluorophenyl ester. Moreover, the signal at $0.85 \mathrm{ppm}$ attributed to the protons which belong to methyl group from the amino acid valine confirms a successful modification. The presence of the RAFT agent can be found by the signal at 7.2 ppm attributed to the aromatic ring. The absence of signals in the ${ }^{19} \mathrm{~F} \mathrm{NMR}$ spectrum indicate that the reaction of the ester groups is complete, within limits of detection. The ATR-FTIR spectrum shows a carbonyl absorption shift from $1782 \mathrm{~cm}^{-1}$ to $1654 \mathrm{~cm}^{-1}$ corresponding to a change of the carbonyl environment from a pentafluorophenyl ester to an amide (Figure S16). The absence of a band at $1715 \mathrm{~cm}^{-1}$ confirms the absence of 
any free carboxylic acid group due to the prior hydrolysis of the pentafluorophenyl group. DMF GPC showed only one peak with a reasonably narrow dispersity $\left(\Theta_{M}=1.26\right)$. Since the ${ }^{19} \mathrm{~F} N M R$ and the ATR-FTIR spectrum supported the full functionalisation of the pentafluorophenyl esters, we used the same protocol for the reaction of pPFPA-75 with the linker-modified peptide GABA(VPGVG), and for pPFPA-100 with GVPGVG and GABA(VPGVG). In each case, NMR spectral data indicated complete functionalisation with the peptide (see Figures S13-15).

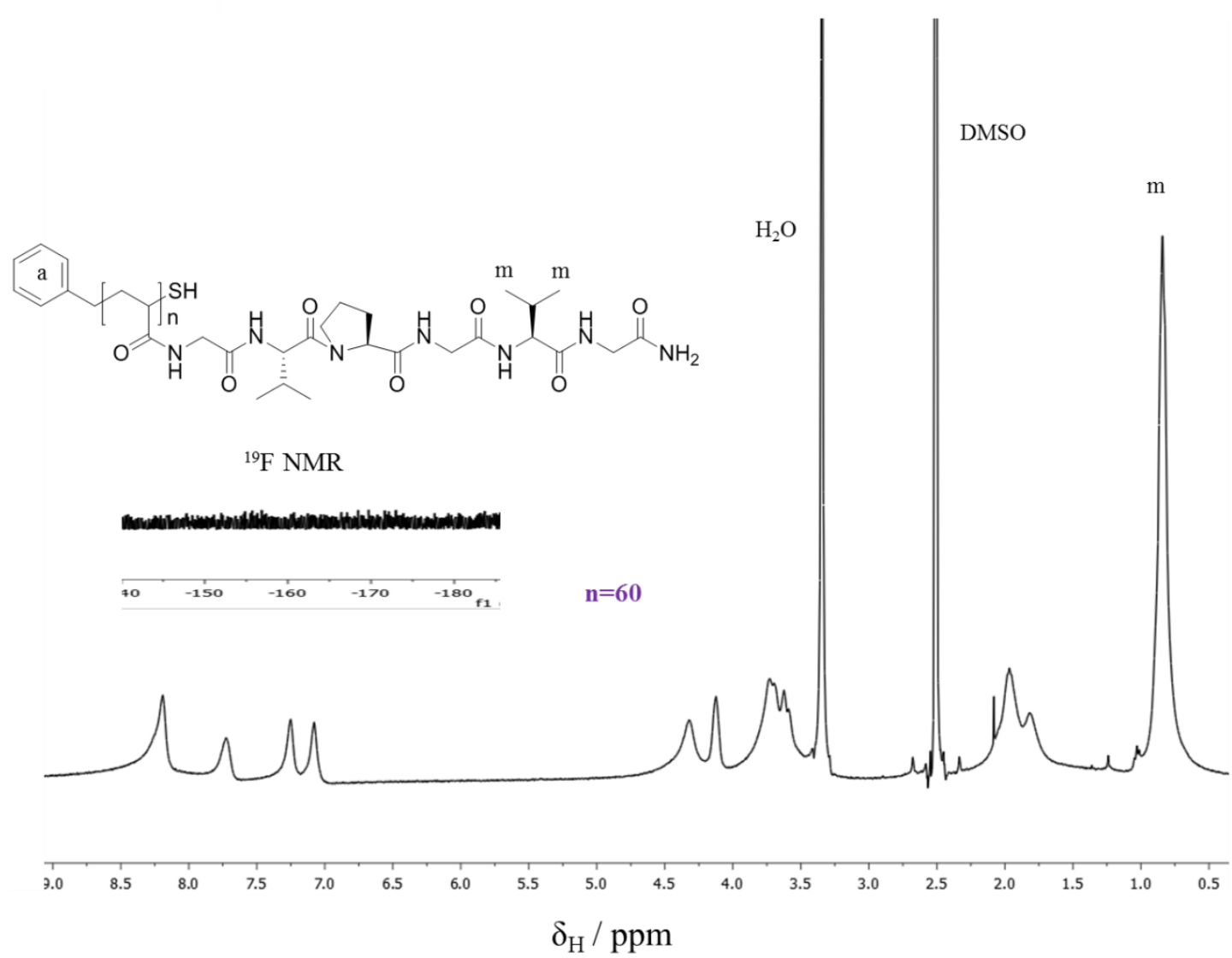

Figure 1. ${ }^{1} \mathrm{H}$ NMR and ${ }^{19} \mathrm{~F}$ NMR spectra of PF75-GVPGVG-NH 2 in $d_{6}$-DMSO.

It has been shown that the transition temperature of linear poly(VPGVG) decreases with increasing chain length. ${ }^{16,17}$ To investigate whether elastin-based side chain polymers (ESPs) display similar behaviour, different chain length polymers were synthesised and studied as shown in Table 4. Each polymer was dissolved in $\mathrm{pH}=7.4$ phosphate buffer at a concentration of $1 \mathrm{mg} \mathrm{mL}^{-1}$. When the number of VPGVG units (DP $)$ in the polymer is increased from 25 to 80 , we see a decrease in transition temperature from higher than 100 ${ }^{\circ} \mathrm{C}$ to $42{ }^{\circ} \mathrm{C}$. For PF25-VPGVG and PF50-VPGVG, the absorbance value increased when temperature increased $\left(15^{\circ} \mathrm{C}-95^{\circ} \mathrm{C}\right)$ in a linear relationship however no transition temperature could be detected. For PF75-VPGVG and PF100-VPGVG, the transition temperature was $49^{\circ} \mathrm{C}$ and $42{ }^{\circ} \mathrm{C}$ respectively as shown in Figure S17. The turbidity measurements clearly showed a decrease in the transition temperature as the chain length was increased. These results are in accord with those of Fernandez-Trillo et al. who showed that the transition temperature decreases with increasing chain length of elastin-based side chain polymers (ESPs) ${ }^{12}$. 
Table 4. Molecular weight data and transition temperatures for elastin-based side chain polymers

\begin{tabular}{llll}
\hline ESP & $\mathrm{DP}_{\mathrm{n}}$ & $\mathrm{M}_{\mathrm{n}, \text { theor }}\left(\mathrm{kg} \cdot \mathrm{mol}^{-1}\right)$ & Transition temperature $\left({ }^{\circ} \mathrm{C}\right)$ \\
\hline PF25-VPGVG & 25 & 12.1 & $/^{\mathrm{a}}$ \\
PF50-VPGVG & 44 & 21.2 & $/^{\mathrm{a}}$ \\
PF75-VPGVG & 60 & 28.9 & 49 \\
PF100-VPGVG & 81 & 39.0 & 42 \\
PF75-GVPGVG & 60 & 32.3 & 76 \\
PF75-GABA(VPGVG) & 60 & 34.0 & 68 \\
PF100-GVPGVG & 81 & 43.6 & 49 \\
PF100-GABA(VPGVG) & 81 & 45.9 & 47 \\
\hline
\end{tabular}

a denotes no transition temperature observed

We also investigated whether the peptide sequence affects the transition temperature. Four polymers of target DP 75 and 100 with different peptide side chains (GVPGVG and GABA(VPGVG)) were synthesised and studied as shown in Table 4. The transition temperatures of polymers PF75-GVPGVG and PF75-GABA(VPGVG) were $76{ }^{\circ} \mathrm{C}$ and $68{ }^{\circ} \mathrm{C}$ respectively while the corresponding polymers with higher DP showed transition temperatures of $49^{\circ} \mathrm{C}$ and $47^{\circ} \mathrm{C}$. These results indicate that, amongst the small set of peptides investigated in this study, the peptide sequence has a small effect on the transition temperature but less so than the polymer chain length.

The second physical parameter of interest is the concentration of the polymer in solution. It has been shown that as the solution concentration of ELP is increased, the transition temperature decreases. ${ }^{16}$ To investigate the effect of solution concentration on transition temperature, three different concentrations of polymers PF100-GVPGVG and PF100-GABA(VPGVG) in PBS solution were prepared and their transition temperatures determined. As shown in Figure $2 \mathrm{a}$ and $\mathrm{b}$, the turbidity measurements clearly confirmed that as the concentration increases, the transition temperature decreases which is the same trend as that observed for linear VPGVG. Urry et al. ${ }^{18},{ }^{19}$ ascribed this concentration effect to the cooperativity of the transition of the peptide secondary structure. This means that when the concentration is increased, the cooperative effect also increases, decreasing the transition temperature. This explanation could also apply to the elastin-based side chain polymers. For polymer PF100-GVPGVG, when the concentration increased from $0.5 \mathrm{mg} \mathrm{mL}^{-1}$ to $2 \mathrm{mg} \mathrm{mL}^{-}$ 1 , the transition temperature changed from $52{ }^{\circ} \mathrm{C}$ to $47{ }^{\circ} \mathrm{C}$. For the polymer PF100-GABA(VPGVG), the transition temperature decreased from $48^{\circ} \mathrm{C}$ to $46^{\circ} \mathrm{C}$ when the concentration was increased.

The third physical parameter investigated is the concentration of $\mathrm{NaCl}$ in the polymer solution. It has been shown that as the concentration of $\mathrm{NaCl}$ is increased, the transition temperature decreases. ${ }^{20}$ To investigate the effect of $\mathrm{NaCl}$ concentration on polymer PF75-GVPGVG and PF75-GABA(VPGVG), four different polymer solutions with different concentrations of $\mathrm{NaCl}$ were prepared and their transition temperatures measured. As shown in Figure $2 \mathrm{c}$ and $\mathrm{d}$, the turbidity measurements clearly confirmed that as the $\mathrm{NaCl}$ concentration increases, the transition temperature decreases which is the same trend as was observed for linear VPGVG. It has been suggested that anions weaken the hydrogen bonding of water to the carbonyl moiety of the amide backbone. ${ }^{20}$ This explanation could also apply to the elastin-based side chain polymers. For polymer PF75-GVPGVG, when the $\mathrm{NaCl}$ concentration increases from 0 to $0.3 \mathrm{M}$, the transition temperature decreases from $76^{\circ} \mathrm{C}$ to $65^{\circ} \mathrm{C}$. As for polymer PF75-GABA(VPGVG), when the NaCl concentration increases, the transition temperature decreases from $68^{\circ} \mathrm{C}$ to $57^{\circ} \mathrm{C}$. 


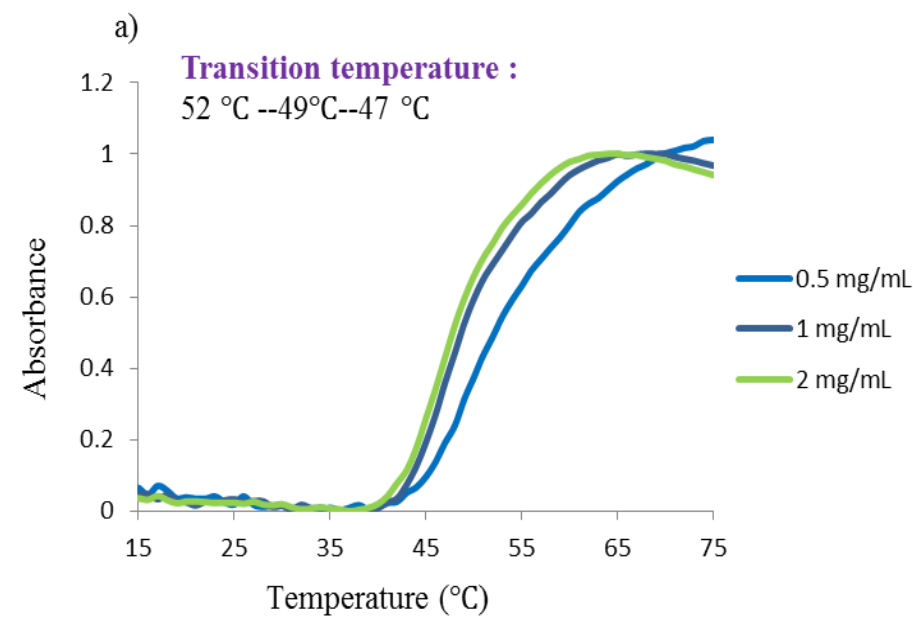

c)

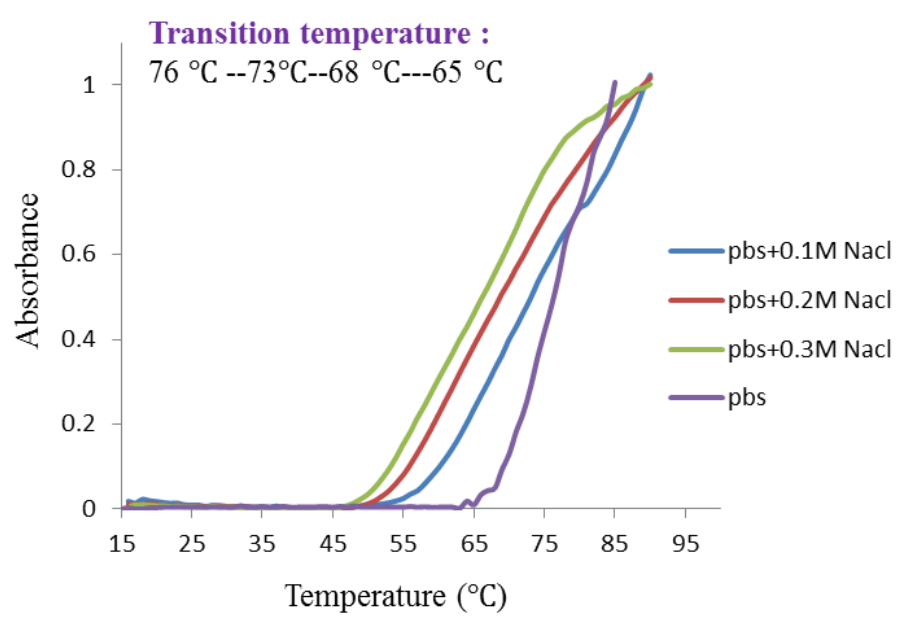

b)

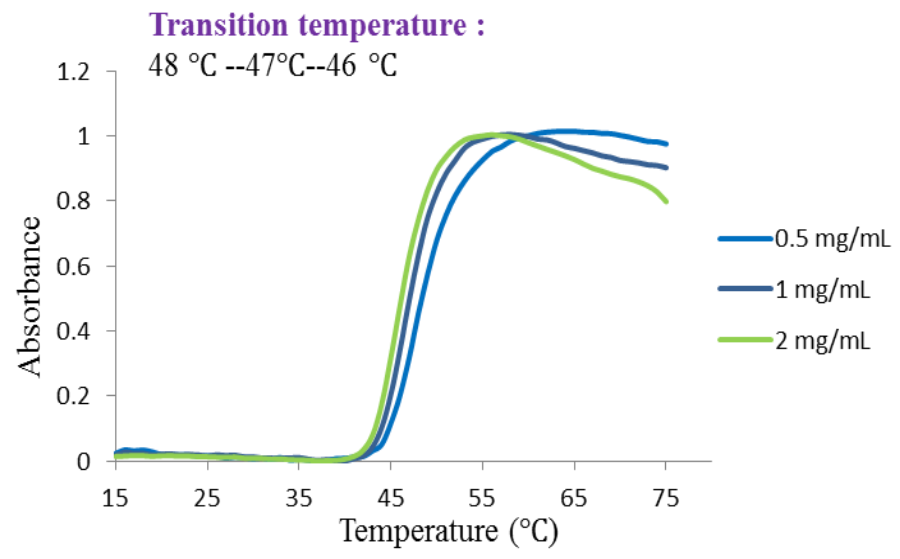

b)

Transition temperature : $68{ }^{\circ} \mathrm{C}--63^{\circ} \mathrm{C}--61{ }^{\circ} \mathrm{C}---57{ }^{\circ} \mathrm{C}$

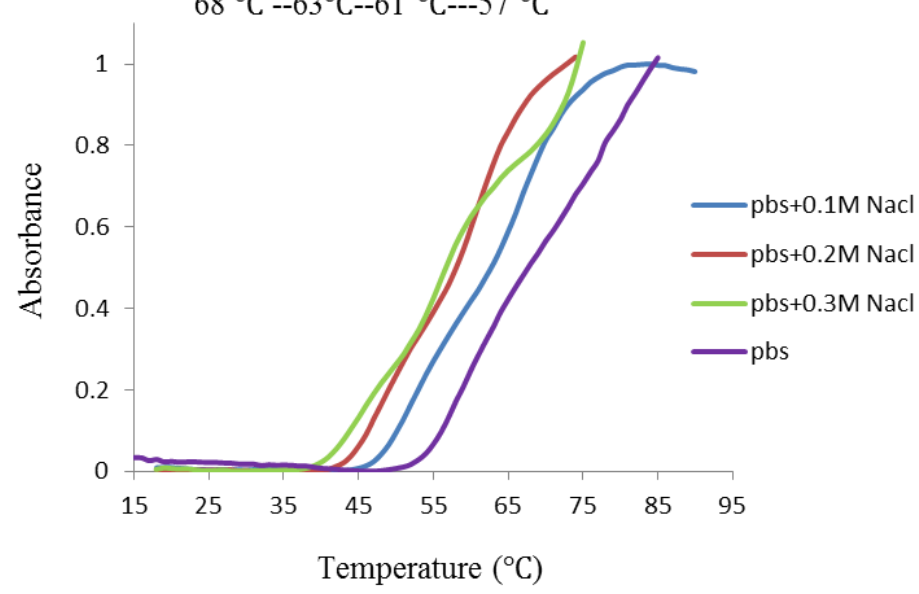

Figure 2. Turbidity measurements of ESP solutions with different concentrations of polymer, and in different salt solution concentrations, as observed by UV-Vis absorbance at $300 \mathrm{~nm}$ : (a) PF100-GVPGVG at $0.5,1.0$ and $2.0 \mathrm{mg} / \mathrm{ml}$; (b) PF100-GABA(VPGVG) at 0.5, 1.0 and $2.0 \mathrm{mg} / \mathrm{ml}$; (c) PF75-GVPGVG in PBS alone and PBS+0.1, 0.2 and 0.3M NaCl; (d) PF75-GABA(VPGVG) in PBS alone and PBS+0.1, 0.2 and $0.3 \mathrm{M} \mathrm{NaCl}$.

In summary, we found that the transition temperature of elastin-based side chain polymers was mainly modulated by the chain length of the polymers. PF25-VPGVG and PF50-VPGVG showed no transition behaviour when the temperature increased in the range $20-100{ }^{\circ} \mathrm{C}$. The transition temperatures of PF75GVPGVG and PF75-GABA(VPGVG) are above $60{ }^{\circ} \mathrm{C}$ whereas PF100-GVPGVG and PF100-GABA(VPGVG) have transition temperatures of $49{ }^{\circ} \mathrm{C}$ and $47{ }^{\circ} \mathrm{C}$ respectively. Due to its higher molecular weight, PF100GABA(VPGVG) has been shown to have the lowest transition temperature as shown in Figure 3. Upon heating to $40{ }^{\circ} \mathrm{C}$, the solution of PF100-GABA(VPGVG) exhibited coacervation and changed from transparent to cloudy white. This coacervation process is reversible; when the solution is cooled down to below the $T_{t}$, the polymer becomes soluble again. 


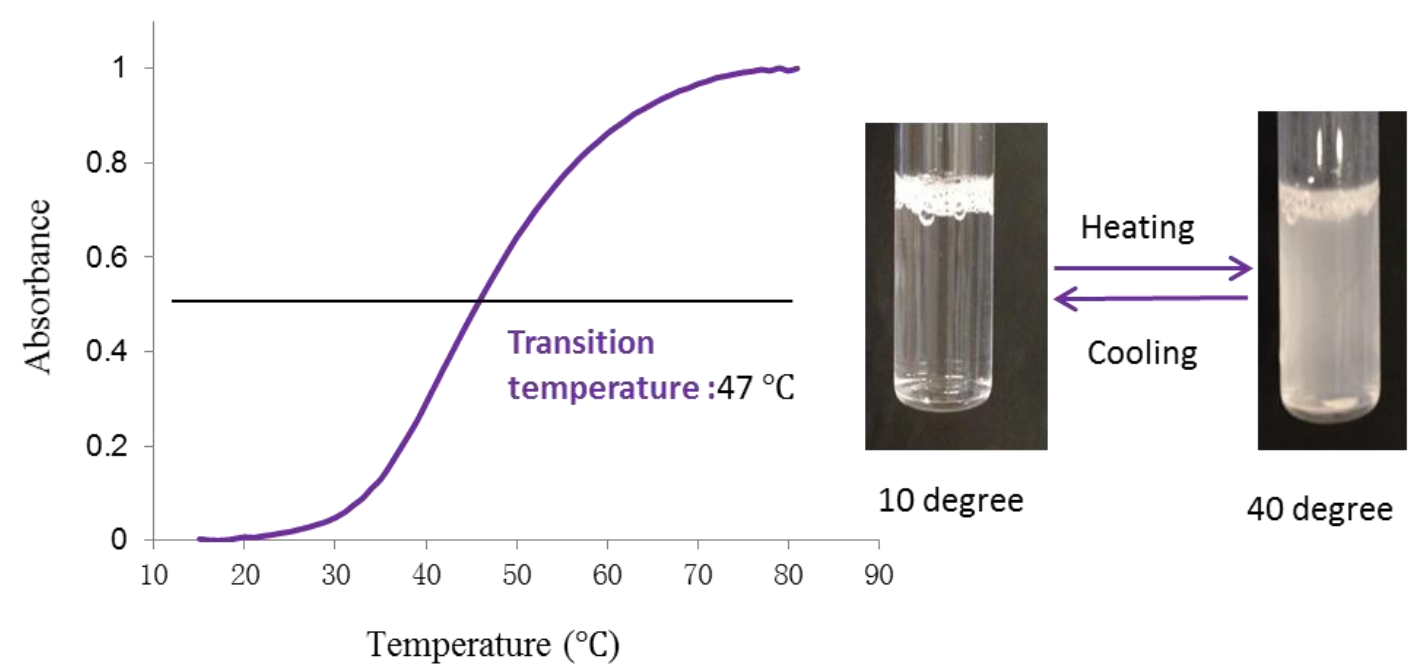

Figure 3. Turbidity measurement of PF100-GABA(VPGVG) $\left(1 \mathrm{mg} \mathrm{mL}^{-1}\right)$ in PBS solution at $\mathrm{pH} 7.4$ as observed by UV-Vis absorbance at $300 \mathrm{~nm}$. Right: visual turbidity change upon increasing temperature.

The temperature dependence of the secondary structure of the peptide residues in PF100GABA(VPGVG) was investigated by circular dichroism. CD spectra were obtained in PBS buffer at a concentration of $0.2 \mathrm{mg} \mathrm{mL}^{-1}$ from $10{ }^{\circ} \mathrm{C}$ to $50{ }^{\circ} \mathrm{C}$ (Figure 4a). At the lowest temperature $\left(10{ }^{\circ} \mathrm{C}\right)$, the mean

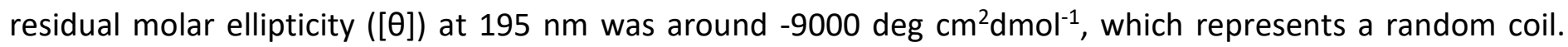
With increasing temperature, obvious increases in [ $\theta]$ at $198 \mathrm{~nm}$ and $208 \mathrm{~nm}$ were observed, which are signatures of $\beta$-turn formation. ${ }^{21}$ The conformational change from random coil to $\beta$-turn occurred smoothly over a temperature range of $10^{\circ} \mathrm{C}$ to $50{ }^{\circ} \mathrm{C}$. Also, there is a decreasing signal at $222 \mathrm{~nm}$ when the temperature is increased, which represents a polypeptide type I/III $\beta$-turn. The trends discussed above are indications of a structural change from a less-ordered state towards an ordered $\beta$-turn state. In Figure $4 b,[\theta]$ increases steadily with increasing temperature at $198 \mathrm{~nm}$. In Figure 4c-d, the temperature was changed from $20^{\circ} \mathrm{C}$ to 50 ${ }^{\circ} \mathrm{C}$ in 3 cycles and the CD signal at $198 \mathrm{~nm}$ was measured. The data show the reversibility of the cloud point behaviour of PF100-GABA(VPGVG). Compared to the behaviour of short elastin-like peptides, the trends in [ $\theta$ ] at $198 \mathrm{~nm}, 208$ and $222 \mathrm{~nm}$ are almost the same. 
a)

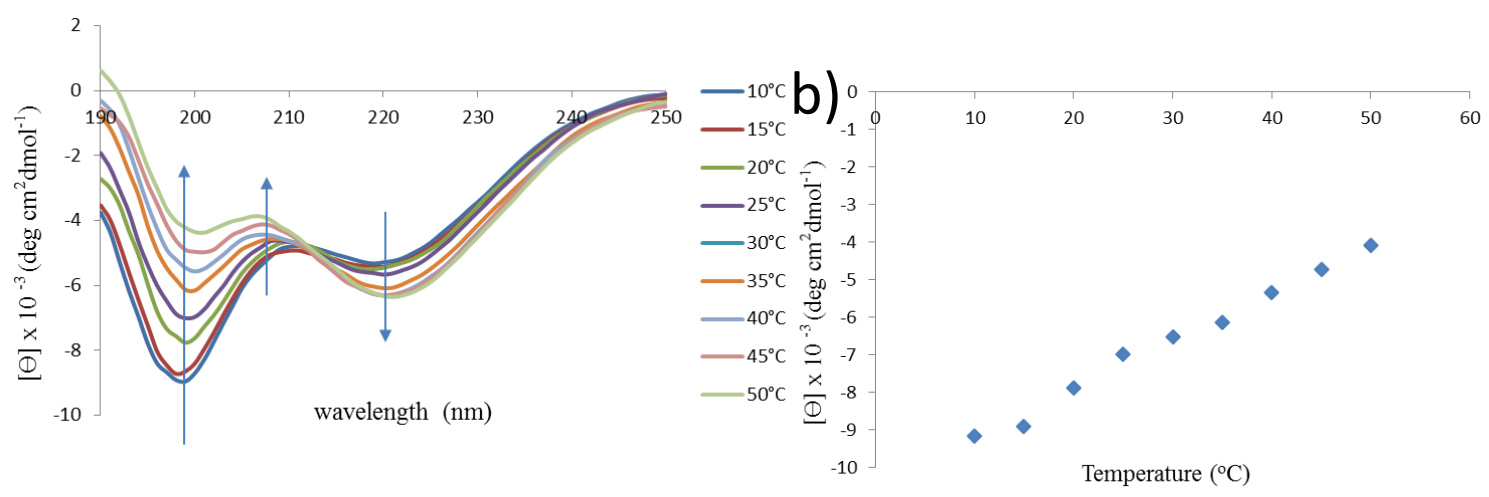

c)

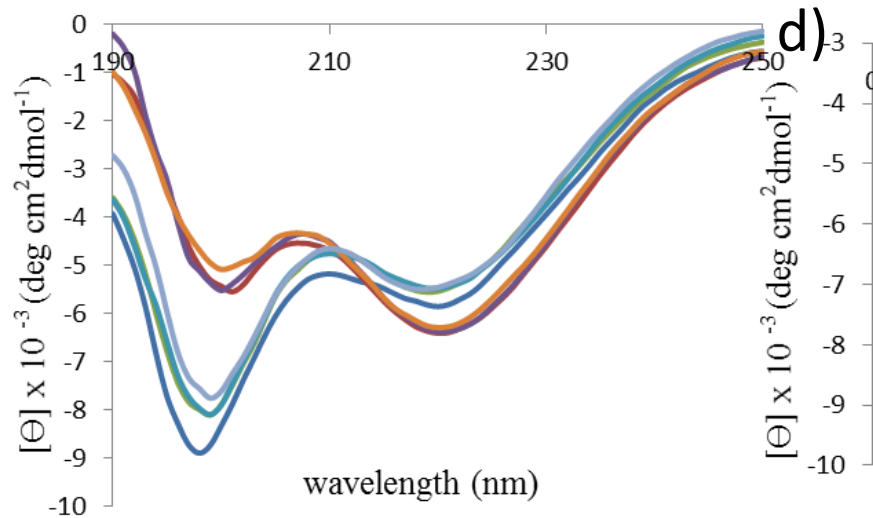

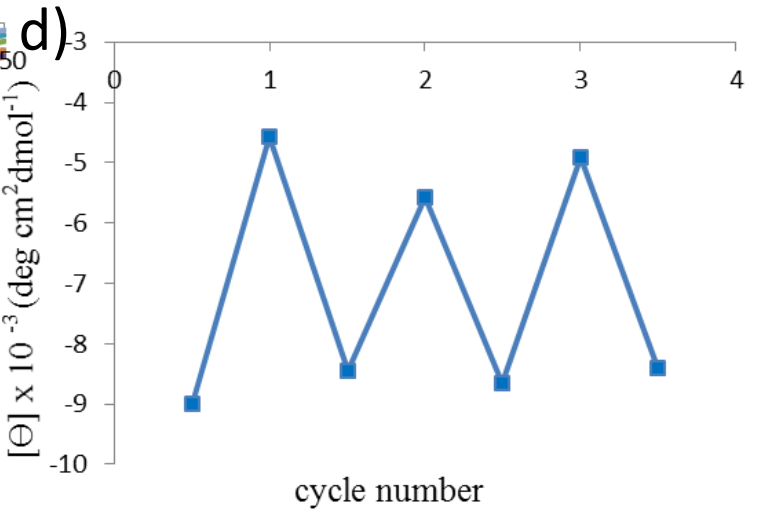

Figure 4. (a) Temperature dependence CD spectra of PF100-GABA(VPGVG) $\left(0.2 \mathrm{mg} \mathrm{mL}^{-1}\right)$ in PBS buffer at $\mathrm{pH}$ 7.4 between $10{ }^{\circ} \mathrm{C}$ and $50{ }^{\circ} \mathrm{C}$; (b) temperature profile of $[\theta]_{198}$ values for PF100-GABA(VPGVG) $\left(0.2 \mathrm{mg} \mathrm{mL}^{-1}\right)$ in PBS buffer at pH 7.4 between $10^{\circ} \mathrm{C}$ and $50^{\circ} \mathrm{C}$; (c-d) CD spectra (c) and the CD signal at $198 \mathrm{~nm}$ (d) of PF100GABA(VPGVG) $\left(0.2 \mathrm{mg} \mathrm{mL}^{-1}\right)$ in PBS buffer at $\mathrm{pH} 7.4$ when cycling the temperature 3 times between $20{ }^{\circ} \mathrm{C}$ and $50^{\circ} \mathrm{C}$.

Citrate-stabilised gold nanoparticles were prepared using the Turkevich-Frens method (see Supporting Material). The preparation of elastin-like peptide functionalised polymer-coated GNPs exploited the reaction between macromolecular thiols and gold nanoparticles with subsequent displacement of citrate ligands. Two elastin-based polymers PF75-GABA(VPGVG) and PF100-GABA(VPGVG) were used to functionalise GNPs to obtain ESP 75 -GNPs and ESP $100-$ GNPs (Figure 5). The ESP-conjugated GNPs were dialyzed (MWCO=50,000 Da) against distilled water for 3 days to remove any unreacted polymers then freeze-dried. The freeze-dried GNP/polymer hybrid nanoparticles were easily re-dispersed in water. 


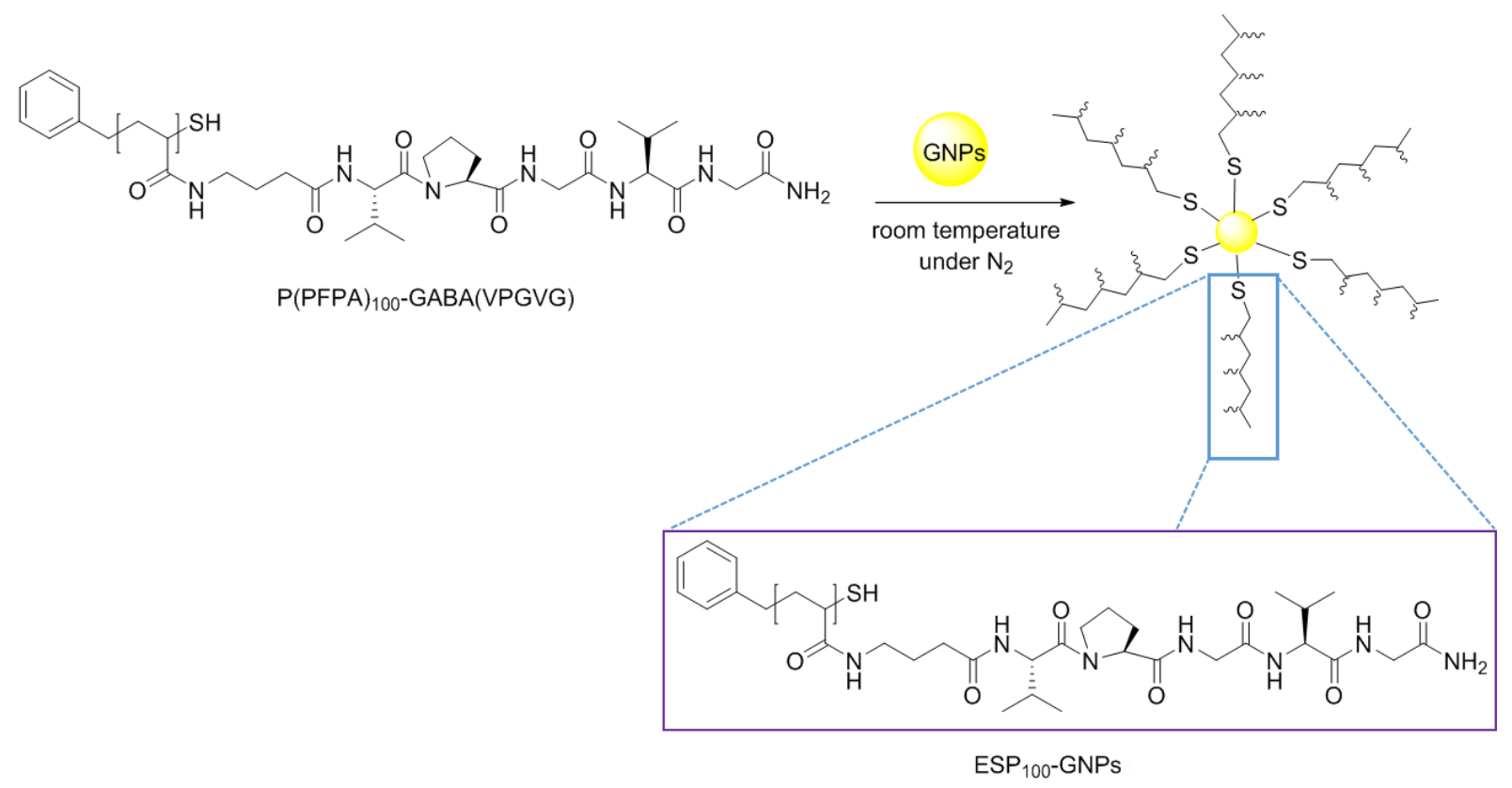

Figure 5. The preparation of polymer-functionalized GNPs (ESP-GNPs).

A TEM image and UV-vis absorption spectrum of ESP $100-$ GNPs are shown in Figure 6a-b. The mean particle diameter by TEM image analysis was found to be $32.7 \pm 6.7 \mathrm{~nm}$. Dynamic light scattering (DLS) gave a mean diameter of $36.8 \mathrm{~nm}$ and a polydispersity of 0.367 (Figure $6 \mathrm{c}$ ).

a)

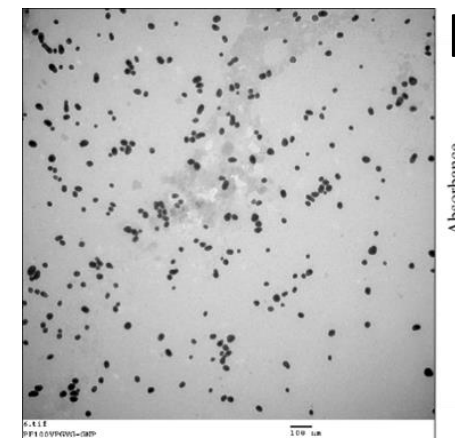

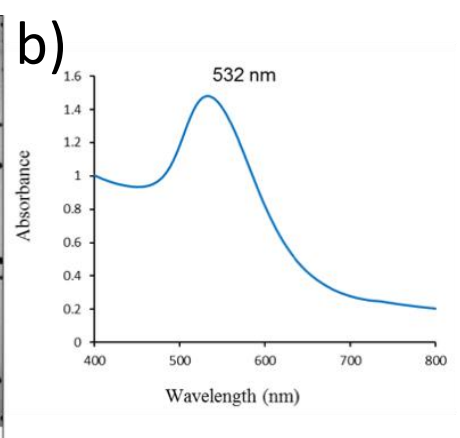

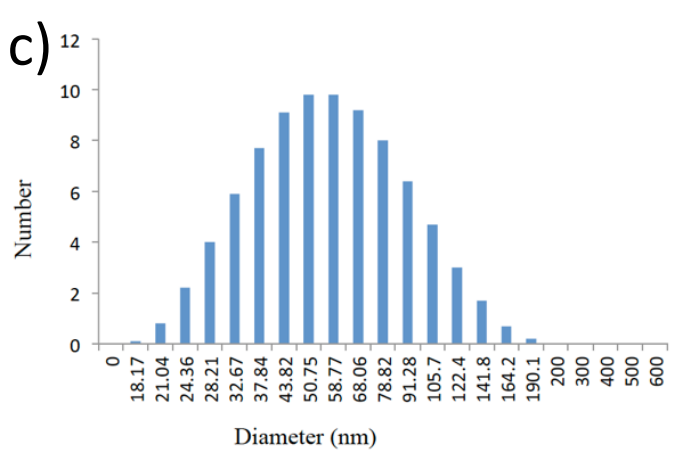

Figure 6. (a) TEM image, (b) UV-Vis data and (c) DLS number distribution of ESP ${ }_{100}-$ GNPs.

We studied the thermo-responsiveness of solutions of ESP-GNPs by UV-vis turbidity measurements. With increasing temperature, the GNP aqueous solution changed colour from red to purple accompanied by a red shift from $532 \mathrm{~nm}$ to $535 \mathrm{~nm}$ in the UV-vis absorption spectrum (Figure 7a-b) at a temperature of around $65^{\circ} \mathrm{C}$, which is close to the transition temperature value of $68^{\circ} \mathrm{C}$ obtained for polymer PF75-GABA(VPGVG) (Table 4). The ESP $75-G N P s$ showed a steady thermal response from $15^{\circ} \mathrm{C}$ to $70{ }^{\circ} \mathrm{C}$ which means that polymer PF75-GABA(VPGVG) anchored onto the GNP surface endowed them with similar thermo-responsive character. 


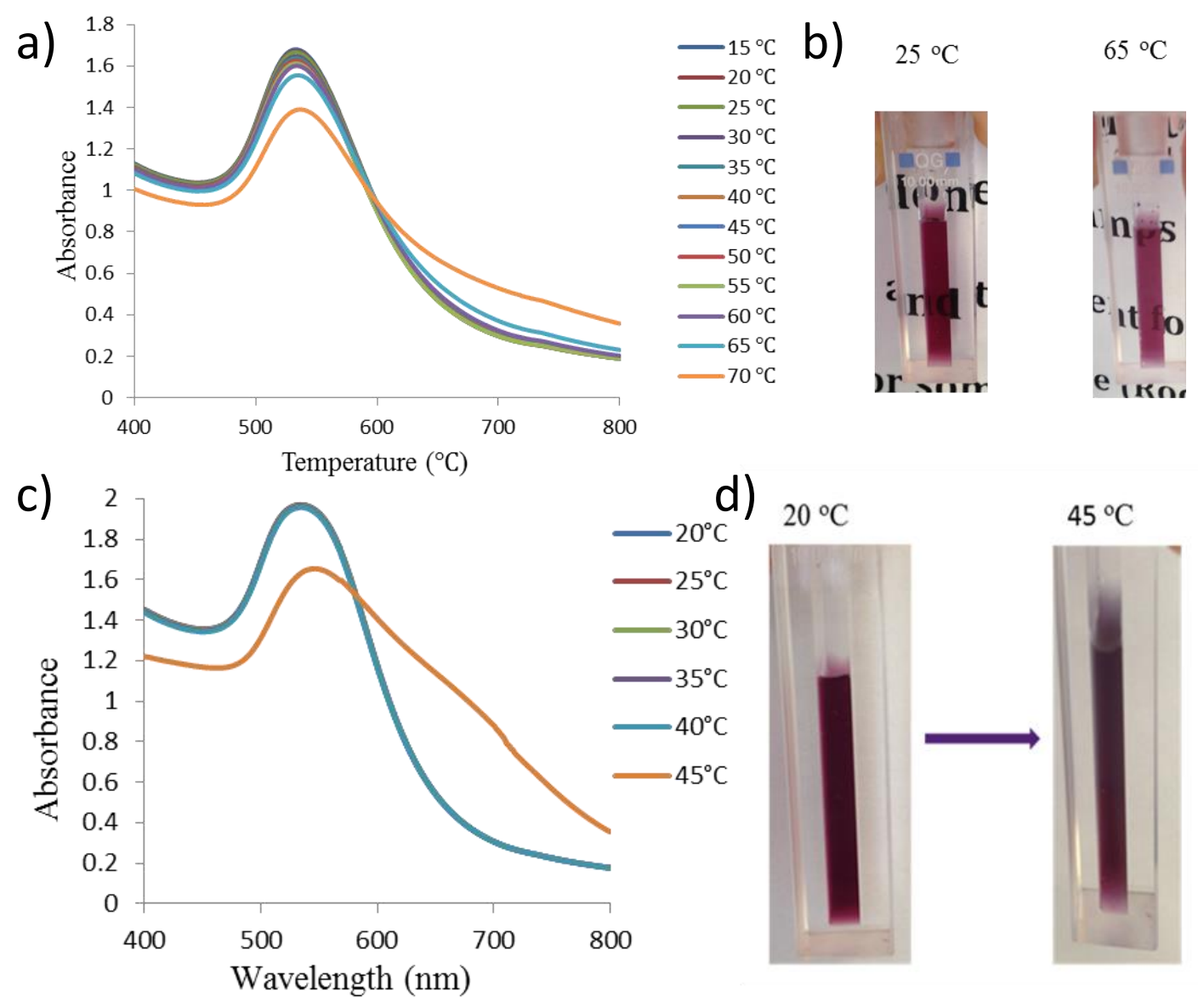

Figure 7. (a) UV-Vis spectra of ESP $75-G N P s\left(0.5 \mathrm{mg} \mathrm{mL}^{-1}\right.$ in PBS buffer at $\left.\mathrm{pH} 7.4\right)$ versus temperature. Each spectrum was taken after an increase of $5^{\circ} \mathrm{C}$ (from $15^{\circ} \mathrm{C}$ to $70{ }^{\circ} \mathrm{C}$ ). (b) photo of ESP $75-G N P s$ dispersed in PBS buffer at $25^{\circ} \mathrm{C}$ and $65{ }^{\circ} \mathrm{C}$, respectively. (c) UV-Vis spectra of ESP $100-\mathrm{GNPs}\left(0.5 \mathrm{mg} \mathrm{mL}^{-1}\right.$ in PBS buffer at pH 7.4) versus temperature. Each spectrum was taken after an increase of $5^{\circ} \mathrm{C}$ (from $20^{\circ} \mathrm{C}$ to $45^{\circ} \mathrm{C}$ ). (d) photo of $\mathrm{ESP}_{100}$-GNPs dispersed in PBS buffer at $25^{\circ} \mathrm{C}$ and $65^{\circ} \mathrm{C}$, respectively.

The same experiment was performed with $\mathrm{ESP}_{100}$-GNPs to test the sensitivity of the functionalized GNPs. After polymer attachment, the solution displayed a colour change and the plasmon resonance absorption peak underwent a shift from $532 \mathrm{~nm}$ to $540 \mathrm{~nm}$ as shown in Figure 7c-d. As ESP $100-\mathrm{GNPs}_{\mathrm{s}}$ have a longer chain and a lower transition temperature than ESP $75-$ GNPs, when attached to GNPs they resulted in a lower transition temperature. The colour of the solution changed from red to purple when the temperature increased from $20^{\circ} \mathrm{C}$ to $45^{\circ} \mathrm{C}$, confirming the assembly process.

The temperature dependency of the secondary structure of ESP $100-\mathrm{GNPs}$ in dilute solution $\left(0.2 \mathrm{mg} \mathrm{mL}^{-1}\right)$ was evaluated using CD spectroscopy. The spectra obtained from $10{ }^{\circ} \mathrm{C}$ to $65^{\circ} \mathrm{C}$ are shown in Figure $8 \mathrm{a}$. The CD spectra of ESP $100-$ GNPs showed the same trend as polymer PF100-GABA(VPGVG) which indicates that the polymer covered the gold nanoparticles, leading to a conformation change when the temperature increased. At the lowest temperature $\left(10{ }^{\circ} \mathrm{C}\right),[\theta]$ was around $-12,000 \mathrm{deg} \mathrm{cm}^{2} \mathrm{dmol}^{-1}$ at $195 \mathrm{~nm}$ which represents a random coil. The CD amplitudes at 195 to $200 \mathrm{~nm}$ decreased with increasing temperature, with a smaller decrease in amplitude at 206 to $212 \mathrm{~nm}$. With increasing temperature, the molar ellipticity [ $\theta$ ] value at 195 to $200 \mathrm{~nm}$ and 206 to $212 \mathrm{~nm}$ increased, which supports increasing $\beta$-turn content. With increasing temperature, there exists a smaller increase in CD amplitudes at $222 \mathrm{~nm}$. This peak is associated with a type I/III $\beta$-turn. The 
data studied here exhibited an increase in [ $\theta$ ] at $198 \mathrm{~nm}$ and $206 \mathrm{~nm}$ with increasing temperature, supporting the folding of the peptide and leading to a $\beta$-turn formation. The conformational transition from random coil to $\beta$-turn occurred gradually over a wide temperature range from $10^{\circ} \mathrm{C}$ to $65^{\circ} \mathrm{C}$.

The change in $[\theta]$ value at $198 \mathrm{~nm}$ was plotted against temperature (Figure $8 \mathrm{~b}$ ). From $10{ }^{\circ} \mathrm{C}$ to $60{ }^{\circ} \mathrm{C}$, the value increased steadily. From these data we can conclude that the transition temperature is around $35^{\circ} \mathrm{C}$. In order to test the reversibility of $\mathrm{ESP}_{100}-\mathrm{GNP}$ assembly, a cyclic thermal response experiment was performed by changing the temperature between $50{ }^{\circ} \mathrm{C}$ and $20^{\circ} \mathrm{C}$ (Figure $8 \mathrm{C}-\mathrm{d}$ ). $\mathrm{CD}$ spectra were acquired at $20{ }^{\circ} \mathrm{C}$ and 50 ${ }^{\circ} \mathrm{C}$ for 3 cycles. These data show that the structural changes of the ESP ${ }_{100}$-GNPs are reversible and can be induced several times without apparent degradation. The CD data obtained also show that the temperatureinduced formation of the $\beta$-turn structure is due to intramolecular and not intermolecular interactions.

a)

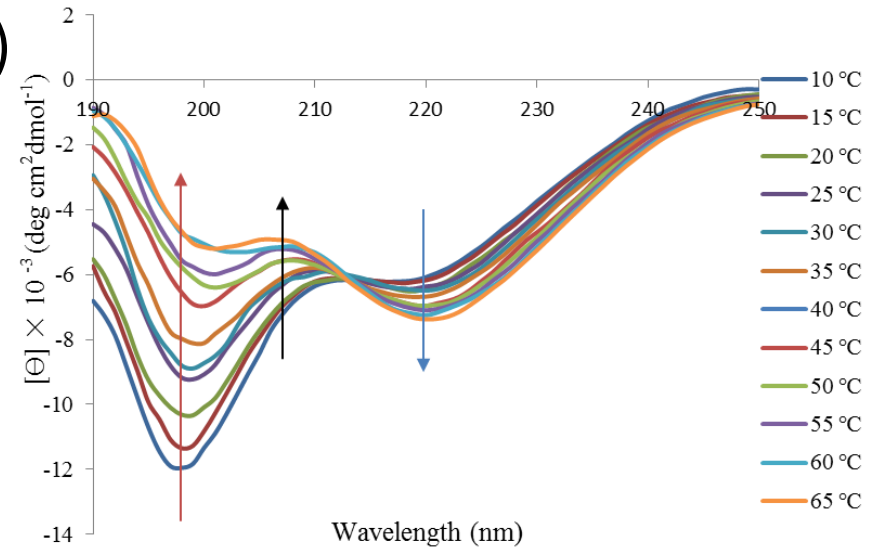

b)

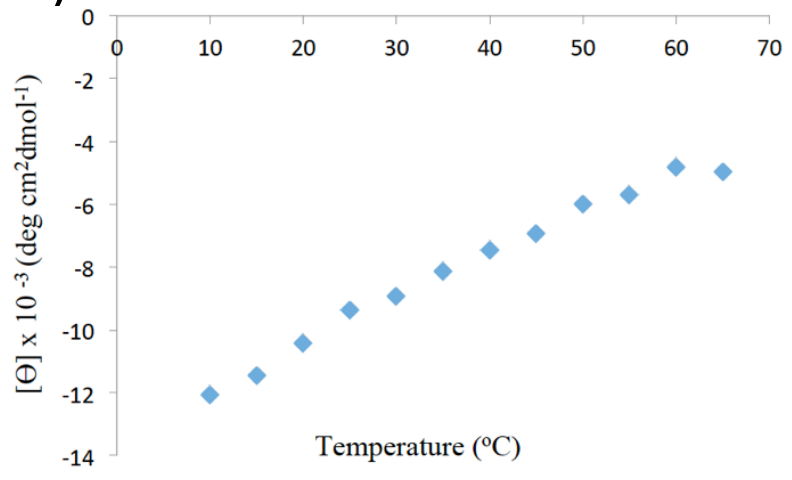

c)

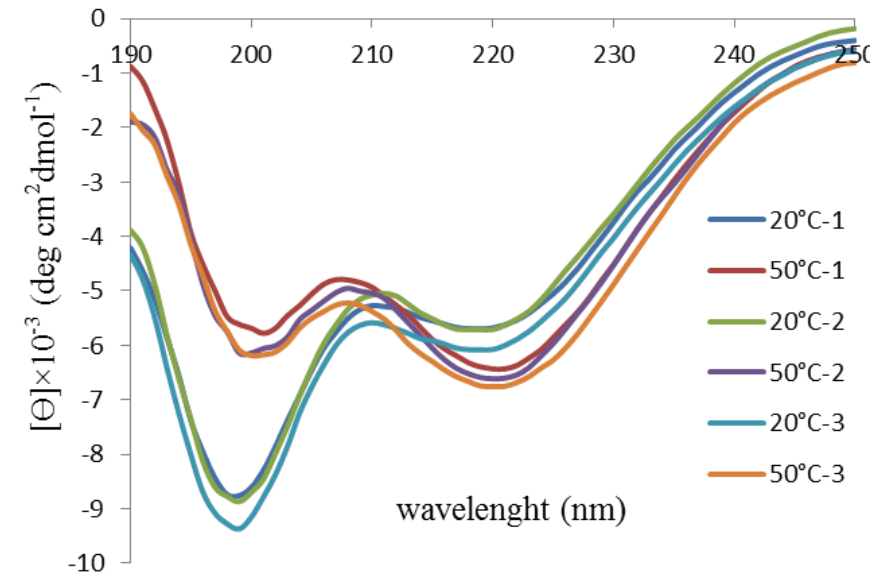

Figure 8. (a) temperature dependence of CD spectra of ESP $100-G N P s\left(0.2 \mathrm{mg} \mathrm{mL}^{-1}\right)$ in PBS buffer at $\mathrm{pH} 7.4$ between $10^{\circ} \mathrm{C}$ and $65^{\circ} \mathrm{C}$. (b) temperature profile of $[\theta]_{198}$ values for $\mathrm{ESP}_{100}-\mathrm{GNPs}\left(0.2 \mathrm{mg} \mathrm{mL}^{-1}\right)$ in PBS buffer at $\mathrm{pH} 7.4$ between $10^{\circ} \mathrm{C}$ and $65^{\circ} \mathrm{C}$. (c-d) CD spectra (c) and CD signal at $198 \mathrm{~nm}$ (d) of ESP $100-\mathrm{GNPs}\left(0.2 \mathrm{mg} \mathrm{mL}^{-1}\right)$ in PBS buffer at $\mathrm{pH} 7.4$ when cycling the temperature 3 times between $20^{\circ} \mathrm{C}$ and $50^{\circ} \mathrm{C}$.

To obtain more direct proof of the aggregation of ESP $100-$ GNPs, the nanoparticles were observed by TEM using samples prepared separately at $20^{\circ} \mathrm{C}$ and $50^{\circ} \mathrm{C}$ (Figure 9). The TEM images taken below and above the phase transition temperature gave more direct evidence of ESP 100 -GNPs aggregation. At low temperature, the nanoparticles are generally well dispersed, although a few aggregates may not be completely excluded. 
When the temperature is increased to $50{ }^{\circ} \mathrm{C}$, aggregation was dominant and accompanied with a colour change of the sample solution as described above.

a)

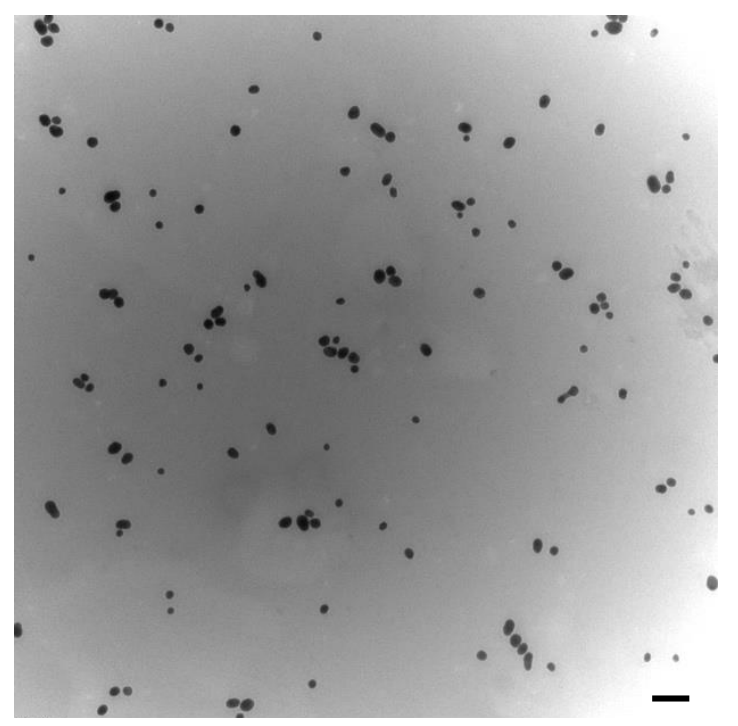

b)

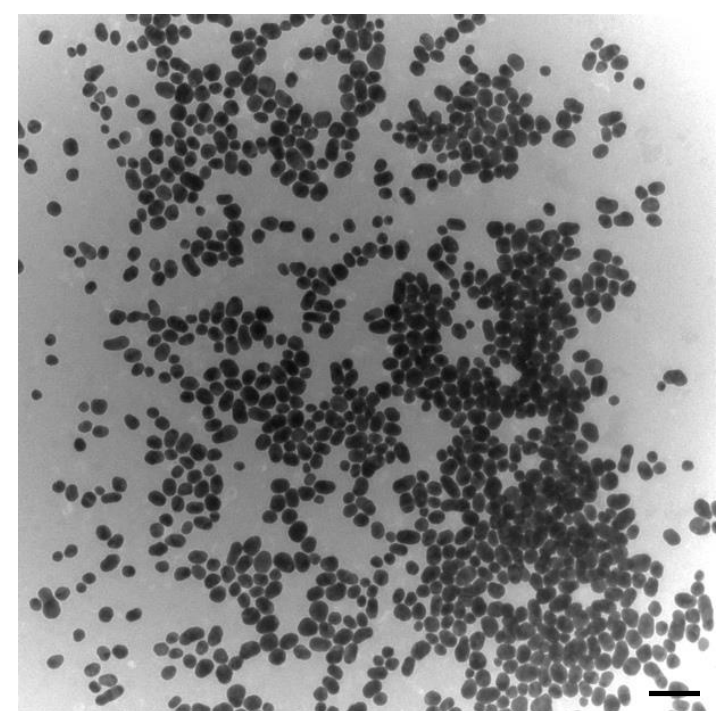

Figure 9. TEM images obtained for dispersions of ESP $100-$ GNPs prepared separately at $20{ }^{\circ} \mathrm{C}$ (a) and $50{ }^{\circ} \mathrm{C}$ (b). Scale bars $=100 \mathrm{~nm}$.

\section{Conclusions}

The preparation of thermoresponsive gold nanoparticles coated with a corona of well-defined elastin-like peptide side-chain polymers has been described. The resulting ESP-GNPs are shown to aggregate reversibly in aqueous solution, at a temperature that is dependent on the transition temperature $\left(T_{t}\right)$ of the attached polymer. Aggregation is accompanied by a corresponding change in the solution conformation of the peptide from random coil to $\beta$-turn, as shown by circular dichroism spectroscopy. The gold nanoparticles functionalised with the longest peptide side-chain polymers display a transition temperature of around $35^{\circ} \mathrm{C}$, making them promising candidate nanomaterials for applications in biotechnology, diagnosis and therapy.

\section{Experimental Section}

General. All solvents and reagents were used as supplied. Coupling agent PyBOP (benzotriazol-1-yloxytripyrrolidinophosphonium hexafluorophosphate) was purchased from Novabiochem. Rink Amide resin with a loading of $0.74 \mathrm{mmol} / \mathrm{g}$ was purchased from Bachem. 9-Fluorenylmethoxy carbamate-protected valine (Fmoc-Val-OH, $>99 \%$ ), glycine (Fmoc-Gly-OH, >99\%), and proline (Fmoc-Pro-OH, >99\%) were purchased from Bachem. NMM ( $N$-methylmorpholine) and piperidine (>99.5\%) were purchased from Sigma-Aldrich. HPLC grade DMF ( $<0.03 \%$ water) was used for coupling reactions and was purchased from Sigma-Aldrich. Trifluoroacetic acid (TFA, 99\%), triisopropylsilane (TIPS, 99\%) and acetic anhydride (>99\%) were purchased from Sigma-Aldrich. 3-Tritylsulfanyl-propionic acid ( $\mathrm{Mpr}(\mathrm{Trt})-\mathrm{OH})$ was purchased from Bachem. Trisodium 
citrate dihydrate $\left(\mathrm{C}_{6} \mathrm{H}_{5} \mathrm{O}_{7} \mathrm{Na}_{3} \bullet 2 \mathrm{H}_{2} \mathrm{O}\right)$ and gold (III) chloride trihydrate $\left(\mathrm{HAuCl}_{4} \bullet 3 \mathrm{H}_{2} \mathrm{O}\right)$ were both obtained from Sigma-Aldrich.

${ }^{1} \mathrm{H},{ }^{13} \mathrm{C}$ and ${ }^{19} \mathrm{~F}$ NMR spectra were recorded using a Varian Mercury-400 or a Bruker Avance-400 spectrometer. $\mathrm{CDCl}_{3}, \mathrm{CD}_{2} \mathrm{Cl}_{2}$ or DMSO-D 6 were used as solvents. All chemical shifts are quoted in parts per million relative to tetramethylsilane $\left(\delta_{\mathrm{H}}=0.00 \mathrm{ppm}\right)$ and coupling constants are given in Hertz $(\mathrm{Hz})$ to the nearest $0.5 \mathrm{~Hz}$.

UV/visible absorption spectroscopy measurements were performed using a Varian CaryBio-100 spectrophotometer equipped with a thermoelectric temperature controller. The samples were measured using a quartz cell with $1 \mathrm{~cm}$ path length at different temperatures and different buffer $\mathrm{pH}$ values. Samples of peptides were prepared in cuvettes sealed with a Teflon stopper and heated at a rate of $1{ }^{\circ} \mathrm{C} / \mathrm{min}$. The measurements were carried out at a fixed wavelength of $300 \mathrm{~nm}$. In this study, in order to calculate the phase transition temperature, all the experimental data were normalized to 1 , and the transition was defined as the temperature at which $50 \%$ of the normalized turbidity was obtained.

FTIR spectra were recorded on a Perkin Elmer 1600 series FTIR spectrometer fitted with a Diamond ATR crystal unit.

Molecular weight analysis was carried out by gel permeation chromatography (GPC) using a Viscotek TDA 302 system with refractive index, viscosity and light scattering detectors. 2 × $300 \mathrm{~mm}$ PLgel $5 \mu \mathrm{m}$ mixed C columns (with a linear range of molecular weight from 200-2,000,000 $\mathrm{g} \mathrm{mol}^{-1}$ ) were employed. THF was used as the eluent with a flow rate of $1.0 \mathrm{mLmin}^{-1}$ at a temperature of $30^{\circ} \mathrm{C}$.

Dynamic light-scattering measurements were conducted using a Brookhaven Instruments 90 Zeta-Plus particle size analyser. Briefly, sample solution $(500 \mu \mathrm{M})$ in phosphate buffer $(10 \mathrm{mM}, \mathrm{pH} 7.4)$ was prepared. Before analysis, all samples were filtered through a $0.2 \mu \mathrm{m}$-pore-size syringe filter to minimise contamination with dust. The diameter of ELP-GNPs was measured between $10^{\circ} \mathrm{C}$ and $60^{\circ} \mathrm{C}$. At each temperature, the sample was incubated for $10 \mathrm{~min}$.

Transmission electron microscopy was conducted on a Hitachi 7600 instrument at an acceleration voltage of $100 \mathrm{kV}$. A small drop of the colloidal gold solution was placed on a carbon-coated copper grid (200 mesh), and excess solution was removed by wicking using filter paper. The grid was dried after allowing the solvent to evaporate for several minutes and turned into a thin film of particles. TEM images were captured from different parts of the grid and with different magnifications.

Circular Dichroism (CD) spectra were recorded on a Jasco J-810 spectropolarimeter equipped with a Jasco PFD$425 \mathrm{~S}$ temperature control unit. Experiments were performed in a quartz cell with a $0.1 \mathrm{~cm}$ path length over the range of $198-250 \mathrm{~nm}$ at various temperatures. Generally, the sample solution $(200 \mu \mathrm{M}, 10 \mathrm{mM}$ phosphate buffer) was injected into the quartz cell. The scan speed is $50 \mathrm{~nm} / \mathrm{min}$.

Peptides were purified by preparative HPLC (C18 column, 10.0 × $250 \mathrm{~mm}, 5 \mu \mathrm{m}$ particle size). Peptides were eluted in $\mathrm{H}_{2} \mathrm{O} / \mathrm{MeCN}+0.1 \%$ trifluoroacetic acid. LC-MS was performed on a LCT Premier XE instrument using a BEH analytical column (C18, $2.1 \times 50 \mathrm{~mm}, 1.7 \mu \mathrm{m}$ particle size).

Synthesis of compounds, polymers and nanomaterials. Synthetic procedures for pentafluorophenyl acrylate (PFPA), the RAFT agent benzyl 2-hydroxyethyl carbonotrithioate, polyPFPA, peptides, elastin-based side-chain polymers (ESPS) and ESP-gold nanoparticles conjugates are presented in the Supplementary Material. 


\section{Acknowledgements}

The authors thank the China Scholarship Council for funding (Scholarship to JZ), and Dr Beth Bromley (Durham University) for assistance with CD spectroscopy.

\section{Supplementary Material}

Spectroscopic data $\left({ }^{1} \mathrm{H}\right.$ NMR, ${ }^{13} \mathrm{C}$ NMR, ${ }^{19} \mathrm{~F}$ NMR, FTIR) for all products can be found in the supplementary material file, together with data confirming peptide identity and purity (LC-MS, analytical HPLC) and cloud point data for ESPs.

\section{References}

1. Zong, J. Y.; Cobb, S. L.; Cameron, N. R., Biomater. Sci. 2017, 5 (5), 872-886. https://doi.org/10.1039/C7BM00006E

2. Laromaine, A.; Koh, L.; Murugesan, M.; Ulijn, R. V.; Stevens, M. M., J. Am. Chem. Soc. 2007, 129 (14), 4156-4157. https://doi.org/10.1021/ja0706504

3. Aili, D.; Selegård, R.; Baltzer, L.; Enander, K.; Liedberg, B., Small 2009, 5 (21), 2445-2452. https://doi.org/10.1002/smll.200900530

4. Si, S.; Raula, M.; Paira, T. K.; Mandal, T. K., ChemPhysChem 2008, 9 (11), 1578-1584. https://doi.org/10.1002/cphc.200800121

5. Si, S.; Mandal, T. K., Langmuir 2007, 23 (1), 190-195. https://doi.org/10.1021/la061505r

6. Lemieux, V.; Adams, P. H. H. M.; van Hest, J. C. M., Chem. Commun. 2010, 46 (18), 3071-3073. https://doi.org/10.1039/b923280j

7. Minelli, C.; Liew, J. X.; Muthu, M.; Andresen, H., Soft Matter 2013, 9 (20), 5119-5124. https://doi.org/10.1039/c3sm50379h

8. Lin, Y. A.; Xia, X. X.; Wang, M.; Wang, Q. R.; An, B.; Tao, H.; Xu, Q. B.; Omenetto, F.; Kaplan, D. L., Langmuir 2014, 30 (15), 4406-4414. https://doi.org/10.1021/la403559t

9. Zong, J. Y.; Cobb, S. L.; Cameron, N. R., J. Mater. Chem. B 2018, 6 (41), 6667-6674. https://doi.org/10.1039/C8TB01827H

10. Urry, D. W.; Shaw, R. G.; Prasad, K. U., Biochem. Biophys. Res. Commun. 1985, 130 (1), 50-57. https://doi.org/10.1016/0006-291X(85)90380-8

11. Fernandez-Trillo, F.; Dureault, A.; Bayley, J. P. M.; van Hest, J. C. M.; Thies, J. C.; Michon, T.; Weberskirch, R.; Cameron, N. R., Macromolecules 2007, 40 (17), 6094-6099. https://doi.org/10.1021/ma070527x

12. Fernandez-Trillo, F.; van Hest, J. C. M.; Thies, J. C.; Michon, T.; Weberskirch, R.; Cameron, N. R., Chem. Commun. 2008, (19), 2230-2232. https://doi.org/10.1039/b800266e

13. Eberhardt, M.; Théato, P., Macromol. Rapid Commun. 2005, 26 (18), 1488-1493. 
https://doi.org/10.1002/marc.200500390

14. Boyer, C.; Davis, T. P., Chem. Commun. 2009, (40), 6029-6031.

https://doi.org/10.1039/b910296e

15. Barner-Kowollik, C., Handbook of RAFT Polymerization. Wiley-VCH: 2008. Weinheim, Germany. https://doi.org/10.1002/9783527622757

16. Meyer, D.; Chilkoti, A., Biomacromolecules 2004, 5 (3), 846-851.

https://doi.org/10.1021/bm034215n

17. Urry, D. W.; Shaw, R. G.; Prasad, K. U., Biochem. Biophys. Res. Commun. 1985, 130 (1), 50-57. https://doi.org/10.1016/0006-291X(85)90380-8

18. Urry, D. W., J. Protein Chem. 1984, 3 (5-6), 403-436.

https://doi.org/10.1007/BF01025061

19. Ayres, L.; Koch, K.; van Hest, J. C. M., Macromolecules 2005, 38 (5), 1699-1704.

https://doi.org/10.1021/ma047923p

20. Cho, Y.; Zhang, Y.; Christensen, T.; Sagle, L. B.; Chilkoti, A.; Cremer, P. S., J. Phys. Chem. B 2008, 112 (44), 13765-13771.

https://doi.org/10.1021/ip8062977

21. Ahmed, Z.; Scaffidi, J. P.; Asher, S. A., Biopolymers 2009, 91 (1), 52-60.

https://doi.org/10.1002/bip.21081 